\title{
The likelihood of observing dust-stimulated phytoplankton growth in waters proximal to the Australian continent
}

\author{
R.A. Cropp, ${ }^{1}$ A.J. Gabric, ${ }^{1}$ M. Levasseur, ${ }^{2}$ G.H. McTainsh, ${ }^{1}$ A. Bowie, ${ }^{3}$ C.S. Hassler, ${ }^{4}$ \\ C.S. Law, ${ }^{5}$ H.A. McGowan, ${ }^{6}$ N. Tindale, ${ }^{7}$ and R.A. Viscarra Rossel. ${ }^{8}$
}

${ }^{1}$ School of Environment, Griffith University, Nathan, Australia

${ }^{2}$ Laval University, Dept. Biology (Quebec-Ocean), Quebec City, PQ G1K 7P4, Canada

${ }^{3}$ Antarctic Climate \& Ecosystems CRC and Institute for Marine and Antarctic Studies, University of Tasmania, Private Bag 80, Hobart, TAS 7001, Australia

${ }^{4}$ Plant Functional Biology and Climate Change Cluster, University of Technology Sydney , Sydney, A ustralia

${ }^{5}$ National Institute for Water \& Atmospheric Research, Wellington, New Zealand

${ }^{6}$ University of Queensland, Climate Res Group, School of Geography Planning \& Environmental Management, Brisbane, Qld, Australia

${ }^{7}$ University of the Sunshine Coast, Maroochydore, Qld 4558, Australia

${ }^{8}$ CSIRO Land and Water, Bruce E. Butler Laboratory, PO Box 1666, Canberra, ACT 2601, Australia 


\begin{abstract}
We develop a tool to assist in identifying a link between naturally occurring aeolian dust deposition and phytoplankton response in the ocean. Rather than examining a single, or small number of dust deposition events, we take a climatological approach to estimate the likelihood of observing a definitive link between dust deposition and a phytoplankton bloom for the oceans proximal to the Australian continent. We use a dust storm index (DSI) to determine dust entrainment in the Lake Eyre Basin (LEB) and an ensemble of modelled atmospheric trajectories of dust transport from the basin, the major dust source in Australia. Deposition into the ocean is computed as a function of distance from the LEB source and the local over-ocean precipitation. The upper ocean's receptivity to nutrients, including dust-borne iron, is defined in terms of time-dependent, monthly climatological fields for light, mixed layer depth and chlorophyll concentration relative to the climatological monthly maximum. The resultant likelihood of a dust-phytoplankton link being observed is then mapped as a function of space and time. Our results suggest that the Southern Ocean (north of $45^{\circ} \mathrm{S}$ ), the North West Shelf, and Great Barrier Reef are ocean regions where a rapid biological response to dust inputs is most likely to be observed. Conversely, due to asynchrony between deposition and ocean receptivity, direct causal links appear unlikely to be observed in the Tasman Sea and Southern Ocean south of $45^{\circ} \mathrm{S}$.
\end{abstract}

\title{
Keywords
}


Dust-phytoplankton link, Aeolian dust, iron limitation, Southern Ocean, Tasman Sea, Great Barrier Reef

\section{Introduction}

The supply of dust-derived nutrients to the global ocean is postulated to be a key control on marine primary production, none more so than in southern hemisphere oceanic regions downwind of arid continental regions, such as South America (Gasso and Stein, 2007; Wolff et al., 2006) and Australia (Cropp et al., 2005; Jickells et al., 2005). Indeed, in high nutrient low chlorophyll (HNLC) regions such as the Southern Ocean (SO), dust-borne iron (Fe) limits primary production, controls phytoplankton species composition, and potentially control the transfer of carbon to the deep ocean, thus affecting atmospheric $\mathrm{CO}_{2}$ concentrations (Boyd et al., 2000; Cassar et al., 2007; Ridgwell, 2002). Conversely, in low nutrient low chlorophyll (LNLC) regions, such as the Mediterranean, tropical North Atlantic (Brust et al., 2011) and tropical waters of northern Australian, dust can stimulate cyanobacterial blooms, which are strongly iron or phosphorus limited or colimited by both nutrients (Mills et al., 2004; Pulido-Villena et al., 2010).

A direct link between a particular dust deposition event and a subsequent phytoplankton bloom has been frustratingly difficult to demonstrate, with some authors suggesting that dust-driven phytoplankton bloom events are rare (Boyd et al., 2009). Notwithstanding the compelling results of several artificial iron-fertilization field experiments in the equatorial Pacific and Southern Oceans (Boyd and Law, 2001; Coale et al., 2004; Martin et al., 
1994), there is only limited and often indirect evidence for an impact of natural dust deposition on phytoplankton growth in Australian regional waters (Gabric et al., 2010; Shaw et al., 2008). In some cases no phytoplankton response has been detected, even after a major dust storm event (Mackie et al., 2008a).

The difficulty in establishing an unequivocal dust-phytoplankton linkage is partly due to the unpredictable and transitory nature of dust events and the operational difficulties of monitoring deposition into the remote oceans. Australia is a spasmodic continental dust source when compared with some northern hemisphere (NH) regions (Shao et al., 2011). Although this creates measurement challenges, the adjacency of the continent to both HNLC and LNLC ocean regions make Australia an ideal laboratory to detect a linkage. Furthermore, Australian mineral dust is Fe-rich by comparison with NH soils (Radhi et al., 2011). The main pathways of dust leaving the Australian continent, are to the northwest over the Indian Ocean, south over the Southern Ocean (SO), and to the southeast over the Tasman Sea in association with the west-to-east passage of cold fronts (McTainsh, 1989). Dust can occasionally be advected north-east over the Great Barrier Reef (GBR) and Pacific Ocean (Shaw et al., 2008). Dust is entrained by warm pre-frontal northerly winds, frontal westerlies and post-frontal southerlies (Strong et al., 2010). During austral spring and summer, the northerly migration of the band of cold fronts contributes to increased dust storm activity over south-eastern Australia (McTainsh, 1998). Indeed, there is a strong seasonality in monthly average dust storm frequency related to wind conditions, rainfall, and vegetation patterns, with peak dust storm activity 
in northern Australia occurring during spring and early summer, while activity in southern Australia peaks later during summer (McTainsh and Leys, 1993).

Variability in ocean biological response to dust-borne Fe inputs has several possible explanations. First, the timing of dust inputs must coincide with upper ocean conditions, predominantly ambient light and mixed layer depth (MLD), that are conducive to a phytoplankton bloom occurring. Second, for a response to Fe addition to occur, the ocean region must be one where Fe limits phytoplankton growth, e.g. High Nutrient Low Chlorophyll (HNLC) areas such as the Southern Ocean (Boyd and Law, 2001), or LNLC regions where diazotroph nitrogen fixation is iron limited (Karl et al., 2002; Law et al., 2011). However, the response to iron addition may be complicated by subtle interactions. These include co-limitation of algal growth by both light and Fe (Feng et al., 2010; Petrou et al., 2011; Sunda and Huntsman, 1997), Fe and silicic acid (Hutchins et al., 2001) or Fe and other micronutrients.

Data on ocean dissolved Fe (dFe) concentrations in the Australian region is sparse and largely limited to N-S transects (e.g. WOCE SR3) in the Southern Ocean (Lai et al., 2008; Lannuzel et al., 2011), the Subantarctic region (Bowie et al., 2009) and the SW Pacific and Tasman Sea (Boyd and Ellwood, 2010; Obata et al., 2008). Generally, mean mixed layer $\mathrm{dFe}$ concentrations in the surface SO are low $(<0.2 \mathrm{nM})$ due to phytoplankton uptake. However, Fe is continuously cycled through the food web in surface waters, and interacts with deeper waters through sedimentation, remineralisation and upwelling, the assessment of its availability is complex and cannot be estimated from 
dFe values alone (Bowie et al., 2009). Additionally, complex interactions between iron chemistry and phytoplankton biology prevent an easy prediction of iron bioavailability to phytoplankton in marine systems (Hassler et al., 2011b). The available data suggests that similar to the bioavailability of inorganic Fe oxyhydroxide colloids, the bioavailable iron associated with dust is generally not available to diatoms, but can be significant for cyanobacteria (Visser et al., 2003).

The Fe in mineral dust is typically insoluble (Baker and Croot, 2008), and a range of solubilities covering four orders of magnitude has been quoted in the literature (Mackie et al., 2006). In the Southern Ocean south of Australia in a study conducted during JanuaryFebruary 2007, dust Fe dissolution values ranged from 0.2-2.5\%, but they were significantly higher (17.7\%) for samples that may have included particles emitted from forest fires that were occurring in southern Australia at the time (Bowie et al., 2009).

Acidification of dust aerosols during atmospheric transport by oxidation with $\mathrm{SO}_{2}$ has been proposed as the primary mechanism for the production of water-soluble forms of Fe (Waeles et al., 2007; Zhuang et al., 1992). However, in sharp contrast to the Northern Hemisphere $(\mathrm{NH})$ where anthropogenic $\mathrm{SO}_{2}$ is plentiful year round (Meskhidze et al., 2005; Meskhidze et al., 2003), the Southern Hemisphere (SH) is relatively unpolluted, and the atmospheric burden of $\mathrm{SO}_{2}$ is closely related to seasonal marine emissions of biogenic compounds such as dimethylsulphide (DMS), which in the Southern Ocean regularly peak during the austral summer (Gabric et al., 1995; Gabric et al., 2010). 
It is also pertinent to note that the solubility and bioavailability of dust derived Fe may be influenced by whether it has been wet or dry deposited. Law et al. (2011 ) report a strong in situ response by diazotrophs to a wet deposition event in the northern Tasman Sea (a LNLC region), which exceeded the response in dust amendment experiments, with direct evidence of increased supply of dissolved Fe during the wet deposition, and indirect evidence of enhanced bioavailability.

Here we address the problem of detecting dust-induced phytoplankton blooms by developing an estimate of the relative likelihood of observing such a link in each month for the oceans surrounding Australia that include both HNLC and LNLC waters. We compute the relative frequency of iron-rich dust deposition and ocean receptivity to dustborne Fe, both pre-conditions for a phytoplankton bloom. Dust transport is simulated by a climatology of modelled air-parcel trajectories from a central location in the Lake Eyre Basin (LEB), the main Australian dust source region (Prospero et al., 2002) which is located in southern central Australia. Ocean receptivity to aeolian nutrients is characterized using local data on surface irradiance and ocean mixed layer depth, overlaid on recognized biogeographic provinces (Longhurst, 2007). The resulting maps are combined to produce a composite map of the likelihood of bloom events, as a function of space and time of year. Results are then discussed considering the regional phytoplankton seasonal dynamic and iron nutritive status, although data on the latter is limited in much of the ocean around Australia. This is the first attempt to provide a comprehensive picture of where and when dust deposition may elicit an observable phytoplankton response in 
ocean waters near Australia. Our approach contrasts with previous attempts at analysis of event-based dust-phytoplankton responses.

\section{Methodology}

Our approach is based on a climatological spatio-temporal perspective that acts as a 'filter' of Australian dust storm events and generates monthly maps which we use to indicate the likelihood that a dust-induced phytoplankton bloom may be observed in a particular region of the proximal ocean during each month of the year. The approach is based on a simple conceptual model of dust mineralogy, entrainment and deposition, and phytoplankton growth that is used to provide a quantitative estimate of the potential to observe a dust-Fe-phytoplankton response.

Several data sets (Table 1) are used to characterize the various relevant atmospheric and oceanic processes. These include soil mineralogy in the LEB (from which we estimate Fe content), atmospheric transport from a source located in the LEB based on modelled air parcel trajectories, the likelihood that an air parcel will contain dust, satellite-derived rain events to simulate wet deposition, satellite-derived solar irradiance at the ocean surface, and climatological nutrient and mixed layer depth in surrounding oceans. These data are synthesised and presented as monthly maps that can be used to categorise regions of ocean according to their potential to demonstrate a dust-phytoplankton connection for each month. 
The relative likelihood of iron-rich dust being available for entrainment is calculated from maps of soil mineralogy of the LEB, giving the percentage abundance of Kaolinite, Illite and Smectite, assuming an average Fe content of 0.2\% for Kaolinite, 2.0\% for Illite, 3.2\% for Smectite and 0\% for any other minerals present (Viscarra Rossel, 2011).

The mineralogy of the soil is assumed constant in time. However, the likelihood of Ferich dust being available for entrainment is modified spatially and intra-annually by vegetation cover, which may also be considered a surrogate for soil moisture (Burgess et al., 1989. We used a Normalised Difference Vegetation Index (NDVI) seasonal climatology from SeaWiFS (Steven et al., 2003) as a proxy for vegetation cover (Shao et al., 2007), so that the likelihood of dust entrainment is given by (1-NDVI). The presence of dust in the LEB lower atmosphere varies seasonally. This seasonality in dust storm activity in the source area is incorporated through the observed Dust Storm Index (DSI), which gives a composite measure of dust storm frequency and intensity during a year (McTainsh and Tews, 2007). The data on DSI and air parcel trajectories is combined to generate monthly relative frequencies of dust being present in the atmosphere above a specific location over the ocean. The frequency $(F r)$ of iron-rich Australian dust being entrained into the atmosphere at any single location in Australia may then be approximated by:

$\operatorname{Fr}($ Dust Entrain $)=(1-N D V I) * \frac{D S I}{D S I_{\max }} *\left(\begin{array}{c}0.002 * F r(\text { Kaolinite }) \\ +0.02 * \operatorname{Fr}(\text { Illite }) \\ +0.032 * \operatorname{Fr}(\text { Smectite })\end{array}\right)$ 
In this analysis we compute equation (1) for a central location in the LEB. We combine this with air-parcel trajectories emanating from this point to compute the transport of dust over the ocean. Trajectories are calculated from a 20-year climatology (1980-2000) of daily air parcel trajectories originating from a point $500 \mathrm{~m}$ above the centre of the LEB and include trajectories at all heights (McGowan and Clark, 2008).

Dust deposition to the ocean can occur through either dry or wet deposition. Dry deposition is calculated as an exponential decay with distance $(\mathrm{km})$ from the LEB source, and wet deposition in a rain event, calculated from a climatology of rainfall data over the ocean from QuikSCAT. The frequency of deposition over the ocean is then :

$\operatorname{Fr}($ Dust Deposition $)=\operatorname{Fr}($ Trajectory $) *\left[e^{-0.0045 * \text { Distance }}+F r(\right.$ Rain $\left.)\right]$

where the fallout rate (0.0045) is an average taken from rates estimated by Uno et al. (2009). The mixed layer average irradiance field experienced by phytoplankton in each season is calculated from monthly climatologies of photosynthetically available radiation (PAR) at the ocean surface $\left(I_{0}\right)$ measured by, and the diffuse attenuation coefficient $\left(k_{490}\right)$ estimated by, SeaWiFS; and mixed layer depth (MLD) estimated by Condie and Dunn (2006) using:

$$
I=I_{0} \int_{z=0}^{z=M I D} e^{-k_{900} z} d z=\frac{I_{0}}{k_{490} M L D}\left(1-e^{-k_{490} M I D}\right)
$$


The mixed layer depth-averaged irradiance field $(I)$ at each point is normalised by the maximum average irradiance $\left(I_{N}\right)$. The normalised irradiance is then multiplied by a weighted indicator of the ecosystem state, here defined as the ratio of the local chlorophyll $a$ concentration $(C h l)$ to the maximum annual concentration, arbitrarily weighted at 50\%. This metric assumes that a causal link between dust deposition and a bloom will be less likely to be detected if the phytoplankton population is already in a bloom phase. We define an ocean receptivity index, $R(0,1)$ :

$$
R=\left(\frac{I}{I_{N}}\right)\left\{1-\frac{C h l}{2 * C h l_{\max }}\right\}
$$

The chlorophyll $a$ weighting was selected in the light of an analysis of the sensitivity of $R$ to the weighting to ensure that the results were not an artefact of the choice of weighting.

Phytoplankton are more likely to respond to dust deposition in regions and during periods of iron-limitation. However, observations are too sparse to construct a spatio-temporal map of iron-limited regions or define regional weights for the ocean receptivity index around Australia. Thus, phytoplankton iron nutritive status is not explicitly included in the model, but will be discussed for each biogeographic province (Figure 3).

Phytoplankton that are iron-limited are more likely to respond to a dust deposition event if the amount of bioavailable Fe supplied by the dust is sufficient to satisfy their requirement for growth. In general, the iron requirement for growth depends on the phytoplankton group as well as their cellular size (Sarthou et al., 2005; Timmermans et al., 2001). Due to persistently low concentrations and biological uptake, iron-limited conditions can be persistent or may develop following the seasonal bloom formation. 
Dust deposition can therefore initiate or prolong a phytoplankton bloom formation. For these reasons results are discussed considering (i) the timing of dust deposition relative to the local bloom phenology, (ii) the iron nutritive status of the phytoplankton, and (iii) the dominant autotrophic taxa reported for each oceanographic region.

\section{Results and Discussion}

Figure 1 shows the seasonal variability in dust storm activity in the LEB as measured by the DSI. Activity is at a minimum during the austral winter, increasing through spring to reach a maximum during the September-December period. Dust storm activity in northern Australia peaks during spring and early summer, coinciding with the seasonal maximum in phytoplankton at lower latitudes, which initiates earlier in the year (Thompson et al., 2011).

Figure 2 shows maps of the overlay of the likelihood of iron-rich dust entrainment in Australia (equation 1), the likelihood of dust deposition into the ocean (equation 2) and the ocean receptivity index (equation 4) for each month of the year. As spatio-temporal variability in dust deposition and ocean receptivity is high, we discuss these results by region and biogeographic province as defined by Longhurst (2007) (see Figure 3).

\subsection{Southern Ocean (SSTC, SANT):}


The provinces of most interest in the SO proximal to the Australian continent are the South Subtropical Convergence Province (SSTC) and the Subantarctic Water Ring Province (SANT). SSTC waters south of Australia are a recognized carbon sinks, however inter-annual variability in the fugacity of $\mathrm{CO}_{2}$ in the water is high (Borges et al., 2008; McNeil and Tilbrook, 2009). Some of the variability of the fugacity of $\mathrm{CO}_{2}$ in these waters is due to inter-annual variability in phytoplankton biomass, that is possibly caused by episodic dust inputs (Gabric et al., 2002). In a series of cruises south of Tasmania that sampled waters from both provinces, McNeil and Tilbrook (2009) found that biological processes dominated the seasonal carbon budget (approximate to 80\%), while air-sea exchange of $\mathrm{CO}_{2}$ (approximate to 10\%) and mixing (approximate to 10\%) were relatively minor processes. Analysis of the satellite ocean colour archive for these provinces reveals a weak seasonal cycle in chlorophyll $a$, with a peak usually occurring in late December or early January and moderate to high inter-annual variability (Johnston and Gabric, 2011). The timing of the chlorophyll peak correlates with dust storm seasonality shown in Figure 1 and the discussion in previous work (Gabric et al., 2002; Gabric et al., 2010).

In the Southern Ocean, diatoms and haptophytes (e.g. coccolithophores, Phaeocystis) are important phytoplankton groups. The iron growth requirement for Antarctic diatoms ranged from $0.59 \mathrm{pM}$ for the small Chaetoceros brevis to $0.19 \mathrm{nM}$ for the chain forming Fragiliariopsis kerguelensis, and up to $1.1 \mathrm{nM}$ for the large Chaetoceros dichaeta (Timmermans et al., 2001), whereas it is $0.4 \mathrm{nM}$ Fe for Phaeocystis antarctica (Sedwick et al., 2007). By comparison, the average dissolved Fe concentration reported for the 
upper $100 \mathrm{~m}$ in the Southern Ocean is $0.1 \mathrm{nM}$ (Moore and Braucher, 2008), suggesting that a small input of bioavailable iron associated with dust deposition can enhance phytoplankton growth in this region.

It has previously been noted that the summer maximum in dust storm activity in southern Australia roughly coincides with the timing of maximum phytoplankton standing stock in the proximal Southern Ocean (Bowie et al., 2011; Gabric et al., 2002). The present analysis shows that dust deposition is moderately frequent over the Southern Ocean south of Australia during spring (Figure 2), when deposition extends well south into the SANT province from September-November. Although the ocean state is not likely to be receptive to iron inputs during this period (due to a deep mixed layer), this dust could add to the inventory of mixed layer particulate and dissolved Fe. The Fe turnover time in the upper ocean can be rapid (Boyd and Ellwood, 2010), so it is not clear whether this spring supply contributes to blooms later in summer. During December-January, when ocean receptivity is higher, dust deposition is mostly confined to the SSTC with little deposition further south in the SANT, although dust can occasionally reach south of $50^{\circ} \mathrm{S}$ in summer under the influence of strong, pre-frontal northerly winds (Gabric et al., 2010). Interestingly, this pattern of dust deposition is consistent with measurements of a strong meridional gradient in dFe along transects in these waters (Cassar et al., 2011; Sedwick et al., 2008).

The SAZ-Sense field study (Jan- Feb. 2007) demonstrated contrasting regimes east and west of Tasmania $\left(46^{\circ} \mathrm{S} 153^{0} \mathrm{E}, 46^{\circ} \mathrm{S} 141^{0} \mathrm{E}\right.$, respectively), with more dust input in the 
eastern region likely fuelling the area with iron (Bowie et al., 2009; Lannuzel et al., 2011; Mongin et al., 2011). Data from SAZ-Sense suggested greater iron limitation in the west of Tasmania and the Polar Frontal Zone south of Australia $\left(54^{\circ} \mathrm{S} 146^{\circ} \mathrm{E}\right)$ compared to the east of Tasmania. The area east of Tasmania is subject to blooms, also thought to be driven by both seasonal Fe supply from southward advection of subtropical waters and by dust deposition (Bowie et al., 2009). Interestingly, dinoflagellates, a phytoplankton group with a high iron requirement (Doucette and Harrison, 1991) dominated the phytoplankton community in the east (77\% of carbon biomass) as compared to the west of Tasmania (17\%, de Salas et al., 2011).

In summary, the Southern Ocean HNLC region south of the continent presents a complex and diverse biological setting that receives moderately frequent dust deposition throughout spring and summer, but is most receptive to dust-derived iron, from December through February, when a link is most likely to be observed. Occasionally dust can be deposited further south over the SANT province, which is most receptive to dust input during December and January.

\subsection{Tasman Sea (TASM):}

Lying between the Coral Sea and the Southern Ocean, this province is characterised by high spatial heterogeneity in biological activity. Longhurst (2007) states that the southern Tasman (east of Tasmania) exhibits a typical spring bloom with chlorophyll maximal in 
late September or early October. However, inter-annual variability is high with the bloom onset varying by as much as four months at a fixed station. Figure 2 suggests that likelihood of dust deposition over the Tasman Sea is relatively low from January through August. Although there is moderate deposition over the south Tasman Sea during early spring (September-October), the ocean receptivity suggests that the conditions may not be appropriate for a bloom to develop at this time. This is consistent with analysis of a dust storm that passed over the south Tasman during October 2003 that produced no discernible phytoplankton response 7 to 30 days after the dust storm (Boyd et al., 2004; Mackie et al., 2008a). Ocean receptivity improves during November-February, however there is a marked contraction of the deposition contours closer to the continent at the start of summer compared with early spring, suggesting only occasional dust inputs during December-January and thus a lower likelihood of observing a dust-induced bloom event. Experimental results from the PINTS study (Hassler et al., unpublished) demonstrated that a $0.5 \mathrm{mg} / \mathrm{L}$ Australian desert dust enrichment in the Tasman Sea $\left(30^{\circ} \mathrm{S} 165^{\circ} \mathrm{E}\right)$ induced an increase of biomass mainly in the pico-plankton and nano-plankton, with a relative increase of diatoms and a decreased of cyanobacteria and prochlorophytes. Given that, at this site, most of the in-situ phytoplankton community lie at depth $(80-110 \mathrm{~m})$ and are dominated by cyanobacteria and prochlorophytes, it is unlikely that this community was influenced by dust input.

The hydrodynamic situation in the western Tasman Sea is complex with a large number of mesoscale eddies originating within the East Australian Current (EAC) that affect vertical mixing and that coincide spatially with phytoplankton blooms (Tilburg et al., 
2002), suggesting factors other than dust deposition are important in this region. In addition, shipboard data collected in the north-eastern Tasman $\left(\sim 29^{\circ} \mathrm{S}, 170^{\circ} \mathrm{E}\right)$ in MarchApril, 2006 during and after a cyclone, showed elevated surface ocean inventories of Fe, suggestive of a dust source, which was probably enhanced by anomalously high wet deposition (Law et al., 2011). Shipboard dust addition experiments showed that diazatophic nitrogen fixation increased by an order of magnitude (Law et al., 2011). The data in Figure 2 suggests a relatively low likelihood of dust deposition during MarchApril in the northern Tasman, underscoring the unusual nature of the cyclonic event as noted by Law et al. (2011)

In summary, due to asynchrony between the timing of dust deposition and ocean receptivity, our analysis suggests the Tasman Sea province is a region where the likelihood of observing a dust-phytoplankton link is low.

\subsection{East Australian Coastal (AUSE):}

The AUSE province extends the entire length of the eastern seaboard so it is convenient to discuss the GBR region in the north and waters south of $27^{\circ} \mathrm{S}$ separately. Riverine sources of nutrients dominate GBR waters during the summer wet season (Brodie et al., 2010). Field sampling indicates that chlorophyll a varies seasonally within regions of the GBR, with mean summer-wet season (December - April) concentrations up to 50\% greater than those in the winter-dry season (May - November). Sub-annual, inter-annual and event-related variations in chlorophyll $a$ concentrations have been observed in 
several zones (Brodie et al., 2007). Unlike Australia’s southern, temperate waters, diazotrophic Cyanobacteria are the dominant phytoplankton by biomass in GBR waters (Furnas et al., 2005; Thompson et al., 2011), with the genus Trichodesmium often forming conspicuous blooms during spring and early summer (Muslim and Jones, 2003).

The nitrogen-fixing ability of Trichodesmium is limited by Fe (Berman-Frank et al., 2001) and recent incubation studies suggest that, although Trichodesmium acquires only dissolved Fe, unlike other phytoplankton, Trichodesmium accelerates the rate of Fe dissolution from oxides and dust, through as yet unspecified cell-surface processes, thereby increasing it’s cellular Fe uptake rate (Rubin et al., 2011; Visser et al., 2003). Atmospheric $\mathrm{N}_{2}$ fixation results in a 5-fold greater iron requirement in Trichodesmium, with other $\mathrm{N}_{2}$ fixing cyanobacteria also having a high iron requirement (Brand, 1991; Kustka et al., 2003). Cellular elemental ratios suggest that Trichodesmium isolated from Australian waters are strongly iron-limited (Fu and Bell, 2003; Kustka et al., 2003). Therefore a link between Trichodesmium abundance and dust deposition, as previously observed in the Atlantic Ocean (Brand, 1991), would not be surprising, especially during the dry season when fluvial dicharges to the GBR is minimal.

Figure 2 suggests a likelihood of low to moderate dust deposition over the GBR from September-December. This has been corroborated by observations of dust storm events that can deposit very high loads of dust over the GBR region during this time of the year (McTainsh et al., 2005). Analysis of the phytoplankton response to high dust storm activity during October 2002 suggested a significant positive anomaly in satellite-derived 
chlorophyll $a$ developed south of Fraser Island in the following weeks, which could not be explained by other mechanisms (Shaw et al., 2008, 2010).

The relative importance of pico-plankton in the AUSE generally decreases relative to nano- and micro-plankton with increasing latitude (Thompson et al., 2011), although the cyanobacterium Synechococcus may bloom in spring (September) in southern waters and comprise up to $60 \%$ of the total biomass. South of Sydney, episodic slope water intrusions are the principal source of nitrogen (nitrate) to coastal waters especially during spring and summer (Pritchard et al., 2003). Coastal phytoplankton blooms appear to occur in response to slope water intrusions (upwelling) irrespective of proximity to other major nutrient sources. A study just north of Sydney, that focussed on the comparison of oceanic and coastal cold-core eddies with inner-shelf and East Australian Current (EAC) waters at the time of the spring bloom (Hassler et al., 2011a) revealed column integrated Chl $a$ was 3-4 times greater in the inner-shelf-EAC frontal zone and adjacent inner-shelf waters compared to the EAC. Phytoplankton analyses and nutrient enrichment experiments showed that nitrogen was the most limiting nutrient in water masses associated with the oceanic cold-core eddy consistent with the observation that diatoms were not dominant, which could favour nitrogen-fixing species already present further north in the Tasman Sea (Hassler et al., 2011a).

Our results suggest that in the northern tropical waters of the AUSE dust deposition during spring, although low (Figure 2), may promote a bloom of diazotrophs, which are sensitive to Fe addition and have previously been observed to respond to dust deposition 
(Lenes et al., 2001). Similarly, in the southern temperate waters of the AUSE, low to moderate dust deposition in November to December appears to coincide with a relatively receptive ocean, suggesting that there is an increased likelihood of observing evidence of a dust-phytoplankton link in this region in summer. However, observation of an unequivocal link between dust deposition and phytoplankton response in this region is unlikely due to its dynamic nature and variability.

\subsection{North-West Shelf (ISSG, AUSW):}

The Indian South Subtropical Gyre (ISSG) province extends from $\sim 10^{\circ} \mathrm{S}$ to the subtropical convergence at $\sim 40^{\circ} \mathrm{S}$. Although most of this province is oligotrophic, satellite imagery suggests higher chlorophyll in the eastern eddy field just west of Australia, during the late austral winter (Longhurst, 2007). The Australia-Indonesia Coastal Province (AUSW) extends from $14^{\circ} \mathrm{N}$ in the SE Timor Sea to Cape Leeuwin at $34^{\circ} \mathrm{S}$ and across the inshore Great Australian Bight, north of the SSTC, discussed above. Although data here is sparse, sampling on the Sahul shelf $\left(18-22^{\circ} \mathrm{S}\right)$ reported much higher chlorophyll values compared with the ISSG region further off-shore, thought to be due to slope water intrusions onto the shelf during summer (Tranter and Leech, 1987).

Significant coral reef ecosystems occur along the northwest coast of Australia in an oceanographic setting somewhat similar to the GBR (Lough, 1998). Corals reefs off the NW Australian coast are less likely to be influenced by freshwater discharges and associated terrestrial impacts than inshore reefs of the GBR, which potentially increases 
the relative importance of dust-derived nutrients. Reported primary production rates near North West Cape $\left(\sim 20-22^{\circ} \mathrm{S}\right)$ display high inter-annual variability, episodically reaching levels of 3-8 $\mathrm{gCm}^{-2}$ day $^{-1}$, characteristic of eastern boundary Ekman upwelling zones elsewhere in the world (Furnas, 2007).

Although there have been very few observations of dFe concentrations in the ocean in this region, Figure 2 suggests the NW Shelf may receive moderate aeolian iron inputs being subject to moderate dust deposition from November through to March. Increased rates of wet deposition during the summer monsoon/cyclone season may also be a contributing factor here, however the quantity of dust transported by the NW dust path is uncertain at this time, although Figure 2 suggests that this dust path may be an important supplier of dust to this region of ocean.

Analysis of satellite ocean colour data suggests that the highest seasonal mean chlorophyll $a$ concentrations along the NW Shelf of Australia occur in summer (JanuaryMarch), but with high inter-annual variability. Chlorophyll concentrations in the offshore oceanic regions were mostly low (Marinelli et al., 2008). However, sampling of marine sediments offshore indicates that aeolian dust may contribute in part to the spatially uniform concentrations of the kaolinite and illite (Gingele et al., 2001). Long term records of biomarker pigments demonstrate that a hot spot of cyanobacteria and prochlorophytes can be found north of $28^{0} \mathrm{~S}$ (Thompson et al., 2011). Due to the high iron requirement of $\mathrm{N}_{2}$ fixation (Law et al., 2011), iron limitation could be expected in this region. 
Comparison of long term data for phytoplankton and nutrient analyses between the AUSW and the AUSE provinces demonstrates interesting regional differences (Thompson et al., 2011). A 7-fold lower average nitrate concentration exists in the AUSW compared to the AUSE region, suggesting a stronger nitrate limitation in the AUSW. Analysis of the relative phytoplankton community composition revealed that cyanobacteria are dominant north of $27.5^{\circ} \mathrm{S}$ for both regions. The AUSW has more pelagophytes, prasinophytes, cryptophytes and chlorophytes, whereas the AUSE has more bacillariophytes and dinophytes (Thompson et al., 2011). Differences in phytoplankton community between AUSW and AUSE likely reflect different seasonality in the pole ward flowing Leeuwin current in the west and the EAC in the east (Thompson et al., 2011), but the lack of dissolved iron and iron limitation measurements hinders the discussion of possible phytoplankton response to dust input.

In summary, the AUSW receives moderate dust deposition from November to February when the ocean receptivity is high. This period also corresponds to the monsoon season suggesting the potential for wet deposition and enhanced Fe solubility. Combined with the presence of iron limited cyanobacteria, this suggests a moderate to high likelihood of observing a dust-phytoplankton link.

\section{Conclusions}


We have presented a climatological analysis of dust transport and deposition from a central location in the LEB from which we develop a tool to assess the likelihood of observing a phytoplankton bloom response in waters around the Australian continent. The dust source strength of the LEB, as indicated by DSI values, is highly seasonal; with an austral winter minimum and summer maximum. Combined with air-parcel trajectory analysis, this seasonality in dust entrainment results in a complex and variable picture of dust transport and deposition over the adjacent oceans.

Our results show that ocean receptivity to dust-derived nutrients is seasonally variable, and often not in synchrony with the timing of dust deposition. This asynchrony between supply and demand for aeolian nutrients is particularly evident over the SO and Tasman Sea during spring, and may explain why some large dust storm events have not produced a clear link with phytoplankton response in these waters. However, our results suggest that deposition during winter-spring supply may increase the inventory of particulate and dissolved Fe in these provinces.

The possible modes of supply of Fe into the Subantarctic zone (corresponding to the SANT province) include Ekman transport of waters from the south during winter (Ellwood et al., 2008), and a combination of atmospheric dust and shelf-derived sediments transported south by the EAC (Bowie et al., 2009). Our SO results suggest the dust source may be important, adding to the upper ocean Fe inventory in spring and potentially stimulating blooms in summer when the ocean state is more receptive. This is 
consistent with the conclusions of recent studies based on field and satellite data analyses in the region (Bowie et al., 2009; Breviere et al., 2006; Gabric et al., 2010).

Relatively low dust deposition occurs over the GBR during spring, however this corresponds to a time of year when diazotrophic cyanobacteria (which are limited by iron), often form large blooms. In the absence of other sources of iron, even a low supply from aeolian sources can elicit a phytoplankton response, as evidenced in the data reported by Law et al. (2011). From November through February a synchrony between dust supply and ocean receptivity exists in the North-West Shelf region, which may contribute to the sometimes high chlorophyll biomass that has been observed there at this time of year. However, while our results suggest a dust-phytoplankton response is possible in this region, a lack of observational data in the NW Shelf region limits our ability to confirm a dust-phytoplankton link in these waters.

There are several caveats in our analysis that should be mentioned. First, we have analysed dust emissions from a single point in the centre of the LEB, and while this provides a good approximation of the paths of dust emissions from Australia, as it is the major dust source region on the continent, other sources also exist. Second, we have based our evaluation of ocean receptivity to aeolian nutrients only on seasonal variation in light, mixed layer depth and surface chlorophyll level. These simplifications ignore the complexity of the real ocean, which includes the possibility of co-limitation of Fe with other nutrients (Harpole et al., 2011), seasonal succession in the phytoplankton community and inter-annual variability in all of these processes. Further, a recent 
modelling study suggests that large fires may supply a potentially important source of soluble iron to the open ocean, compared to dust (Ito, 2012). The main dust storm season in Australia peaks in summer-autumn (Mackie et al., 2008b), when drought and strong winds concurrently enhance bushfire activity. Bushfires are extensive throughout Australia, as evidenced through the 2012-13 austral summer when drought, extreme heat and strong winds fuelled fires in the southeast of the country (Bureau of Meteorology, 2013). Bushfire smoke may be an additional and more soluble source of Fe to the ocean (Guieu et al., 2005; Lou et al., 2008), either directly or indirectly through merging of dust and smoke, which enhances atmospheric processing (e.g., by oxalates) (Ito, 2011). However, this is not likely to influence the climatological approach we have taken here as modelling work by Ito (Ito, 2011) indicates that on climatological scales the deposition of soluble iron into the ocean is small compared to the input from dust. However, Ito's work also suggests that individual fire events may be significant contributors of soluble iron to the ocean, and this

Despite the computational simplicity of the analysis, the climatological approach has revealed novel aspects of the regional dust-phytoplankton link that could not be easily derived from event-based studies. For example, the results show where and when in Australian regional waters a synchrony between dust deposition and ocean receptivity should translate into a phytoplankton response. Ultimately, this tool may be useful to better target field campaigns and observations of over-ocean deposition. This will help select events for the subject of high-resolution modelling of dust transport to improve our 
understanding of the complex link between aeolian sources of nutrients and phytoplankton response.

\section{Acknowledgements}

This manuscript is the outcome of a dust workshop held at Griffith University in Brisbane, Australia on 11 - 13 May 2010. We thank the Atmospheric Environment Research Centre and the Office for Research of Griffith University for sponsoring the event. We also thank Stephane Blain, Phillip Boyd, Alan Butcher, John Leys, Doug Mackie, Richard Matear, John Norbury, Yaping Shao, Craig Strong, Bronte Tilbrook and Mitsuo Uematsu for their contributions to the workshop. 


\section{References}

Baker, A.R., Croot, P.L., 2008. Atmospheric and marine controls on aerosol iron solubility in seawater. Mar. Chem.

Berman-Frank, I., Cullen, J.T., Shaked, Y., Sherrell, R.M., Falkowski, P.G., 2001. Iron availability, cellular iron quotas, and nitrogen fixation in Trichodesmium. Limnology and Oceanography 46, 1249-1260.

Borges, A.V., Tilbrook, B., Metzl, N., Lenton, A., Delille, B., 2008. Inter-annual variability of the carbon dioxide oceanic sink south of Tasmania. Biogeosciences 5, 141-155.

Bowie, A.R., Griffiths, F.B., Dehairs, F., Trull, T.W., 2011. Oceanography of the subantarctic and Polar Frontal Zones south of Australia during summer: Setting for the SAZ-Sense study. Deep-Sea Research Part Ii-Topical Studies in Oceanography 58, 2059-2070.

Bowie, A.R., Lannuzel, D., Remenyi, T.A., Wagener, T., Lam, P.J., Boyd, P.W., Guieu, C., Townsend, A.T., Trull, T.W., 2009. Biogeochemical iron budgets of the Southern Ocean south of Australia: Decoupling of iron and nutrient cycles in the subantarctic zone by the summertime supply. Glob. Biogeochem. Cycle 23.

Boyd, P.W., Ellwood, M.J., 2010. The biogeochemical cycle of iron in the ocean. Nat. Geosci. 3, 675-682.

Boyd, P.W., Law, C.S., 2001. The Southern Ocean Iron RElease Experiment (SOIREE)introduction and summary. Deep Sea Res. II 48, 2425-2438.

Boyd, P.W., Mackie, D.S., Hunter, K.A., 2009. Aerosol iron deposition to the surface ocean - Modes of iron supply and biological responses. Mar. Chem. doi:10.1016/j.marchem.2009.01.008.

Boyd, P.W., McTainsh, G., Sherlock, V., Richardson, K., Nichol, S., Ellwood, M., Frew, R., 2004. Episodic enhancement of phytoplankton stocks in New Zealand subantarctic waters: Contribution of atmospheric and oceanic iron supply. Glob. Biogeochem. Cycle 18.

Boyd, P.W., Watson, A.J., Law, C.S., Abraham, E.R., Trull, T., Murdoch, R., Bakker, D.C.E., Bowie, A.R., Buesseler, K.O., Chang, H., Charette, M., Croot, P., Downing, K., Frew, R., Gall, M., Hadfield, M., Hall, J., Harvey, M., Jameson, G., LaRoche, J., Liddicoat, M.I., Ling, R., Maldonado, M.T., McKay, R.M., Nodder, S., Pickmere, S., Pridmore, R., Rintoul, S., Safi, K., Sutton, P., Strzepek, R., Tanneberger, K., Turner, S., Waite, A., Zeldis, J., 2000. A mesoscale phytoplankton bloom in the polar Southern Ocean stimulated by iron fertilization. Nature 407, 695-702.

Brand, L.E., 1991. Minimum iron requirements of marine-phytoplankton and the implications for the biogeochemical control of new production. Limnology and Oceanography 36, 1756-1771. 
Breviere, E., Metzl, N., Poisson, A., Tilbrook, B., 2006. Changes of the oceanic CO2 sink in the Eastern Indian sector of the Southern Ocean. Tellus Ser. B-Chem. Phys. Meteorol. 58, 438-446.

Brodie, J., De'ath, G., Devlin, M., Furnas, M., Wright, M., 2007. Spatial and temporal patterns of near-surface chlorophyll a in the Great Barrier Reef lagoon. Marine and Freshwater Research 58, 342-353.

Brodie, J., Schroeder, T., Rohde, K., Faithful, J., Masters, B., Dekker, A., Brando, V., Maughan, M., 2010. Dispersal of suspended sediments and nutrients in the Great Barrier Reef lagoon during river-discharge events: conclusions from satellite remote sensing and concurrent flood-plume sampling. Marine and Freshwater Research 61, 651-664.

Brust, J., Schulz-Bull, D.E., Leipe, T., Chavagnac, V., Waniek, J.J., 2011. Descending particles: From the atmosphere to the deep ocean - A time series study in the subtropical NE Atlantic. Geophysical Research Letters 38.

Cassar, N., Bender, M.L., Barnett, B.A., Fan, S., Moxim, W.J., Levy, H., Tilbrook, B., 2007. The Southern Ocean biological response to Aeolian iron deposition. Science 317, 1067-1070.

Cassar, N., DiFiore, P.J., Barnett, B.A., Bender, M.L., Bowie, A.R., Tilbrook, B., Petrou, K., Westwood, K.J., Wright, S.W., Lefevre, D., 2011. The influence of iron and light on net community production in the Subantarctic and Polar Frontal Zones. Biogeosciences 8, 227-237.

Coale, K.H., Johnson, K.S., Chavez, F.P., Buesseler, K.O., Barber, R.T., Brzezinski, M.A., Cochlan, W.P., Millero, F.J., Falkowski, P.G., Bauer, J.E., Wanninkhof, R.H., Kudela, R.M., Altabet, M.A., Hales, B.E., Takahashi, T., Landry, M.R., Bidigare, R.R., Wang, X.J., Chase, Z., Strutton, P.G., Friederich, G.E., Gorbunov, M.Y., Lance, V.P., Hilting, A.K., Hiscock, M.R., Demarest, M., Hiscock, W.T., Sullivan, K.F., Tanner, S.J., Gordon, R.M., Hunter, C.N., Elrod, V.A., Fitzwater, S.E., Jones, J.L., Tozzi, S., Koblizek, M., Roberts, A.E., Herndon, J., Brewster, J., Ladizinsky, N., Smith, G., Cooper, D., Timothy, D., Brown, S.L., Selph, K.E., Sheridan, C.C., Twining, B.S., Johnson, Z.I., 2004. Southern ocean iron enrichment experiment: Carbon cycling in high- and low-Si waters. Science 304, 408-414.

Condie, S.A., Dunn, J.R., 2006. Seasonal characteristics of the surface mixed layer in the Australasian region: implications for primary production regimes and biogeography. Mar. Freshw. Res. 57, 569-590.

Cropp, R.A., Gabric, A.J., McTainsh, G.H., Braddock, R.D., Tindale, N., 2005. Coupling between ocean biota and atmospheric aerosols: Dust, dimethylsulphide, or artifact? Glob. Biogeochem. Cycle 19.

de Salas, M.F., Eriksen, R., Davidson, A.T., Wright, S.W., 2011. Protistan communities in the Australian sector of the Sub-Antarctic Zone during SAZ-Sense. Deep-Sea Research Part Ii-Topical Studies in Oceanography 58, 2135-2149.

Doucette, G.J., Harrison, P.J., 1991. Aspects of iron and nitrogen nutrition in the red tide dinoflagelllate Gymnodinium-Sanguineum. Mar. Biol. 110, 165-173.

Ellwood, M.J., Boyd, P.W., Sutton, P., 2008. Winter-time dissolved iron and nutrient distributions in the Subantarctic Zone from 40-52S; 155-160E. Geophysical Research Letters 35. 
Feng, Y., Hare, C.E., Rose, J.M., Handy, S.M., DiTullio, G.R., Lee, P.A., Smith, W.O., Peloquin, J., Tozzi, S., Sun, J., Zhang, Y., Dunbar, R.B., Long, M.C., Sohst, B., Lohan, M., Hutchins, D.A., 2010. Interactive effects of iron, irradiance and CO2 on Ross Sea phytoplankton. Deep-Sea Research Part I-Oceanographic Research Papers 57, 368-383.

Fu, F.X., Bell, P.R.F., 2003. Growth, N-2 fixation and photosynthesis in a cyanobacterium, Trichodesmium sp., under Fe stress. Biotechnol. Lett. 25, 645649.

Furnas, M., 2007. Intra-seasonal and inter-annual variations in phytoplankton biomass, primary production and bacterial production at North West Cape, Western Australia: Links to the 1997-1998 El Nino event. Continental Shelf Research 27, 958-980.

Furnas, M., Mitchell, A., Skuza, M., Brodie, J., 2005. In the other 90\%: phytoplankton responses to enhanced nutrient availability in the Great Barrier Reef Lagoon. Marine Pollution Bulletin 51, 253-265.

Gabric, A.J., Ayers, G.P., Sander, G.C., 1995. Independent marine and atmospheric model estimates of the sea-air flux of dimethylsulfide in the Southern Ocean. Geophys. Res. Lett. 22, 3521-3524.

Gabric, A.J., Cropp, R., Ayers, G.P., McTainsh, G., Braddock, R., 2002. Coupling between cycles of phytoplankton biomass and aerosol optical depth as derived from SeaWiFS time series in the Subantarctic Southern Ocean - art. no. 1112. Geophysical Research Letters 29, 1112-1112.

Gabric, A.J., Cropp, R.A., McTainsh, G.H., Johnston, B.M., Butler, H., Tilbrook, B., Keywood, M., 2010. Australian dust storms in 2002-2003 and their impact on Southern Ocean biogeochemistry. Glob. Biogeochem. Cycle 24.

Gasso, S., Stein, A.F., 2007. Does dust from Patagonia reach the sub-Antarctic Atlantic ocean? Geophysical Research Letters 34.

Gingele, F.X., De Deckker, P., Hillenbrand, C.D., 2001. Clay mineral distribution in surface sediments between Indonesia and NW Australia - source and transport by ocean currents. Mar. Geol. 179, 135-146.

Guieu, C., Roy-Barman, M., Leblond, N., Jeandal, C., Souhart, M., Le Cann, B., Dufour, A., Bournot, C., 2005. Vertical particle flux in the northeast Atlantic Ocean (POMME experiment). J. Geophys. Res. 110, 1-21.

Harpole, W.S., Ngai, J.T., Cleland, E.E., Seabloom, E.W., Borer, E.T., Bracken, M.E.S., Elser, J.J., Gruner, D.S., Hillebrand, H., Shurin, J.B., Smith, J.E., 2011. Nutrient co-limitation of primary producer communities. Ecol. Lett. 14, 852-862.

Hassler, C.S., Djajadikarta, J.R., Doblin, M.A., Everett, J.D., Thompson, P.A., 2011a. Characterisation of water masses and phytoplankton nutrient limitation in the East Australian Current separation zone during spring 2008. Deep-Sea Res. Part IITop. Stud. Oceanogr. 58, 664-677.

Hassler, C.S., Schoemann, V., Nichols, C.M., Butler, E.C.V., Boyd, P.W., 2011b. Saccharides enhance iron bioavailability to Southern Ocean phytoplankton. Proc. Natl. Acad. Sci. U. S. A. 108, 1076-1081.

Hutchins, D.A., Sedwick, P.N., DiTullio, G.R., Boyd, P.W., Queguiner, B., Griffiths, F.B., Crossley, C., 2001. Control of phytoplankton growth by iron and silicic acid 
availability in the subantarctic Southern Ocean: Experimental results from the SAZ Project. Journal of Geophysical Research-Oceans 106, 31559-31572.

Ito, A., 2011. Mega fire emissions in Siberia: potential supply of bioavailable iron from forests to the ocean. Biogeosciences 8, 1679-1697.

Ito, A., 2012. Contrasting the Effect of Iron Mobilization on Soluble Iron Deposition to the Ocean in the Northern and Southern Hemispheres. J. Meteorol. Soc. Jpn. 90A, 167-188.

Jickells, T.D., An, Z.S., Andersen, K.K., Baker, A.R., Bergametti, G., Brooks, N., Cao, J.J., Boyd, P.W., Duce, R.A., Hunter, K.A., Kawahata, H., Kubilay, N., laRoche, J., Liss, P.S., Mahowald, N., Prospero, J.M., Ridgwell, A.J., Tegen, I., Torres, R., 2005. Global iron connections between desert dust, ocean biogeochemistry, and climate. Science 308, 67-71.

Johnston, B.M., Gabric, A.J., 2011. Interannual variability in estimated biological productivity in the Australian sector of the Southern Ocean in 1997-2007. Tellus Series B-Chemical and Physical Meteorology 63, 266-286.

Karl, D., Michaels, A., Bergman, B., Capone, D., Carpenter, E., Letelier, R., Lipschultz, F., Paerl, H., Sigman, D., Stal, L., 2002. Dinitrogen fixation in the world's oceans. Biogeochemistry 57, 47-98

Kustka, A.B., Sanudo-Wilhelmy, S.A., Carpenter, E.J., Capone, D., Burns, J., Sunda, W.G., 2003. Iron requirements for dinitrogen- and ammonium-supported growth in cultures of Trichodesmium (IMS 101): Comparison with nitrogen fixation rates and iron: carbon ratios of field populations. Limnology and Oceanography 48, 1869-1884.

Lai, X., Norisuye, K., Mikata, M., Minami, T., Bowie, A.R., Sohrin, Y., 2008. Spatial and temporal distribution of $\mathrm{Fe}, \mathrm{Ni}, \mathrm{Cu}$ and $\mathrm{Pb}$ along 140 degrees $\mathrm{E}$ in the Southern Ocean during austral summer 2001/02. Marine Chemistry 111, 171-183.

Lannuzel, D., Bowie, A.R., Remenyi, T., Lam, P., Townsend, A., Ibisanmi, E., Butler, E., Wagener, T., Schoemann, V., 2011. Distributions of dissolved and particulate iron in the sub-Antarctic and Polar Frontal Southern Ocean (Australian sector). DeepSea Research Part Ii-Topical Studies in Oceanography 58, 2094-2112.

Law, C.S., Woodward, E.M.S., Ellwood, M.J., Marriner, A., Bury, S.J., Safi, K.A., 2011. Response of surface nutrient inventories and nitrogen fixation to a tropical cyclone in the southwest Pacific. Limnology and Oceanography 56, 1372-1385.

Lenes, J.M., Darrow, B.P., Cattrall, C., Heil, C.A., Callahan, M., Vargo, G.A., Byrne, R.H., Prospero, J.M., Bates, D.E., Fanning, K.A., Walsh, J.J., 2001. Iron fertilization and the Trichodesmium response on the West Florida shelf. Limnol. Oceanogr. 46, 1261-1277.

Longhurst, A.R., 2007. Ecological Geography of the Sea, 2nd ed. Academic Press, San Diego.

Lou, C., Mahowald, N., Bond, T., Chuang, P.Y., Artaxo, P., Siefert, R.L., Chen, Y., Schauer, J., 2008. Combustion iron distribution and deposition. Global Biogeochem. Cycles 22.

Lough, J.M., 1998. Coastal climate of northwest Australia and comparisons with the Great Barrier Reef: 1960 to 1992. Coral Reefs 17, 351-367. 
Mackie, D.S., Boyd, P.W., McTainsh, G.H., Tindale, N.W., Westberry, T.K., Hunter, K.A., 2008a. Biogeochemistry of iron in Australian dust: From eolian uplift to marine uptake. Geochemistry Geophysics Geosystems 9.

Mackie, D.S., Boyd, P.W., McTainsh, G.H., Tindale, N.W., Westberry, T.K., Hunter, K.A., 2008b. Biogeochemistry of iron in Australian dust: From eolian uplift to marine uptake. Geochem. Geophys. Geosyst 9, 1-24.

Mackie, D.S., Peat, J.M., McTainsh, G.H., Boyd, P.W., Hunter, K.A., 2006. Soil abrasion and eolian dust production: Implications for iron partitioning and solubility. Geochemistry Geophysics Geosystems 7.

Marinelli, M.A., Lynch, M.J., Pearce, A.F., 2008. A remote sensing study of the phytoplankton spatial-temporal cycle in the south eastern Indian Ocean. J. Appl. Remote Sens. 2.

Martin, J.H., K.H. Coale, K.S. Johnson, e.a., 1994. Testing the iron hypothesis in ecosystems of the equatorial Pacific Ocean. Nature 371, 123-129.

McGowan, H., Clark, A., 2008. Identification of dust transport pathways from Lake Eyre, Australia using Hysplit. Atmos. Environ. 42, 6915-6925.

McNeil, B.I., Tilbrook, B., 2009. A seasonal carbon budget for the sub-Antarctic Ocean, South of Australia. Marine Chemistry 115, 196-210.

McTainsh, G., Chan, Y.C., McGowan, H., Leys, J., Tews, K., 2005. The 23rd October 2002 dust storm in eastern Australia: characteristics and meteorological conditions. Atmos. Environ. 39, 1227-1236.

McTainsh, G.H., 1989. QUATERNARY AEOLIAN DUST PROCESSES AND SEDIMENTS IN THE AUSTRALIAN REGION. Quat. Sci. Rev. 8, 235-253.

McTainsh, G.H., A.W. Lynch, E.K. Tews, 1998. Climatic controls upon dust storm occurrence in eastern Australia. J. Arid Environment 39, 457-466.

McTainsh, G.H., Leys, J.F., 1993. Wind erosion, in: McTainsh, G.H., Boughton, W.C. (Eds.), Land Degradation Processes in Australia. Longman Chesire, Melbourne.

McTainsh, G.H., Tews, E.K., 2007. Soil Erosion by wind: Dust Storm Index (DSI), National Monitoring and Evaluation Framework, prepared for the National Land and Water Resources Audit (NLWRA), 27pp.

Meskhidze, N., Chameides, W.L., Nenes, A., 2005. Dust and pollution: A recipe for enhanced ocean fertilization? J. Geophys. Res.-Atmos. 110.

Meskhidze, N., Chameides, W.L., Nenes, A., Chen, G., 2003. Iron mobilization in mineral dust: Can anthropogenic SO2 emissions affect ocean productivity? Geophysical Research Letters 30.

Mills, M.M., Ridame, C., Davey, M., La Roche, J., Geider, R.J., 2004. Iron and phosphorus co-limit nitrogen fixation in the eastern tropical North Atlantic. Nature 429, 292-294.

Mongin, M., Matear, R., Chamberlain, M., 2011. Simulation of chlorophyll and iron supplies in the Sub Antarctic Zone South of Australia. Deep-Sea Research Part IiTopical Studies in Oceanography 58, 2126-2134.

Moore, J.K., Braucher, O., 2008. Sedimentary and mineral dust sources of dissolved iron to the world ocean. Biogeosciences 5, 631-656.

Muslim, I., Jones, G., 2003. The seasonal variation of dissolved nutrients, chlorophyll a and suspended sediments at Nelly Bay, Magnetic Island. Estuar. Coast. Shelf Sci. $57,445-455$. 
Obata, H., Shitashima, K., Isshik, K., Nakayama, E., 2008. Iron, manganese and aluminum in upper waters of the western South Pacific ocean and its adjacent seas. J. Oceanogr. 64, 233-245.

Petrou, K., Hassler, C.S., Doblin, M.A., Shelly, K., Schoemann, V., van den Enden, R., Wright, S., Ralph, P.J., 2011. Iron-limitation and high light stress on phytoplankton populations from the Australian Sub-Antarctic Zone (SAZ). DeepSea Research Part Ii-Topical Studies in Oceanography 58, 2200-2211.

Pritchard, T.R., Lee, R.S., Ajani, P.A., Rendell, P.S., Black, K., Koop, K., 2003. Phytoplankton responses to nutrient sources in coastal waters off southeastern Australia. Aquatic Ecosystem Health and Management 6, 105-117.

Prospero, J.M., Ginoux, P., Torres, O., Nicholson, S.E., Gill, T.E., 2002. Environmental characterization of global sources of atmospheric soil dust identified with the Nimbus 7 Total Ozone Mapping Spectrometer (TOMS) absorbing aerosol product. Rev. Geophys. 40.

Pulido-Villena, E., Rerolle, V., Guieu, C., 2010. Transient fertilizing effect of dust in Pdeficient LNLC surface ocean. Geophys. Res. Lett. 37.

Radhi, M., Box, M.A., Box, G.P., Keywood, M.D., Cohen, D.D., Stelcer, E., Mitchell, R.M., 2011. Size-resolved chemical composition of Australian dust aerosol during winter. Environmental Chemistry 8, 248-262.

Ridgwell, A.J., 2002. Dust in the Earth system: The biogeochemical linking of land, air, and sea,. Philosophical Transactions of the Royal Society A 360, 2905-2924.

Rubin, M., Berman-Frank, I., Shaked, Y., 2011. Dust- and mineral-iron utilization by the marine dinitrogen-fixer Trichodesmium. Nat. Geosci. 4, 529-534.

Sarthou, G., Timmermans, K.R., Blain, S., Treguer, P., 2005. Growth physiology and fate of diatoms in the ocean: a review. J. Sea Res. 53, 25-42.

Sedwick, P.N., Bowie, A.R., Trull, T.W., 2008. Dissolved iron in the Australian sector of the Southern Ocean (CLIVAR SR3 section): Meridional and seasonal trends. Deep-Sea Research Part I-Oceanographic Research Papers 55, 911-925.

Sedwick, P.N., Garcia, N.S., Riseman, S.F., Marsay, C.M., DiTullio, G.R., 2007. Evidence for high iron requirements of colonial Phaeocystis antarctica at low irradiance. Biogeochemistry 83, 83-97.

Shao, Y., Chappell, A., Huang, J., Z., L., McTainsh, G., Mikami, M., Tanaka, T., Wang, X.J., Wyrwoll, K.-H., S., Y., 2011. Dust Cycle: An Emerging Core Concept in Earth System Science. AEOLIAN RESEARCH 2, 181-204.

Shao, Y., Leys, J., McTainsh, G., Tews, K., 2007. Numerical simulation of the October 2002 dust event in Australia. J. Geophys. Res. 112, 1-12.

Shaw, E.C., Gabric, A.J., McTainsh, G.H., 2008. Impacts of aeolian dust deposition on phytoplankton dynamics in Queensland coastal waters. Marine and Freshwater Research 59, 951-962.

Shaw, E.C., Gabric, A.J., McTainsh, G.H., 2010. Response to comment on 'Impacts of aeolian dust deposition on phytoplankton dynamics in Queensland coastal waters'. Marine and Freshwater Research 61, 504-506.

Steven, M.D., Malthus, T.J., Baret, F., Xu, H., Chopping, M.J., 2003. Intercalibration of vegetation indices from different sensors. Remote Sens. Environ. 88, 412-422. 
Strong, C.L., Parsons, K., McTainsh, G.H., Sheehan, A., 2010. Dust transporting wind systems in the lower Lake Eyre Basin, Australia AEOLIAN RESEARCH doi:10.1016/j.aeolia.2010.11.001.

Sunda, W.G., Huntsman, S.A., 1997. Interrelated influence of iron, light and cell size on marine phytoplankton growth. Nature 390, 389-392.

Thompson, P.A., Bonham, P., Waite, A.M., Clementson, L.A., Cherukuru, N., Hassler, C., Doblin, M.A., 2011. Contrasting oceanographic conditions and phytoplankton communities on the east and west coasts of Australia. Deep-Sea Research Part IiTopical Studies in Oceanography 58, 645-663.

Tilburg, C.E., Subrahmanyam, B., O'Brien, J.J., 2002. Ocean color variability in the Tasman Sea. Geophys. Res. Lett. 29.

Timmermans, K.R., Davey, M.S., van der Wagt, B., Snoek, J., Geider, R.J., Veldhuis, M.J.W., Gerringa, L.J.A., de Baar, H.J.W., 2001. Co-limitation by iron and light of Chaetoceros brevis, C-dichaeta and C-calcitrans (Bacillariophyceae). Marine Ecology-Progress Series 217, 287-297.

Tranter, D.J., Leech, G.S., 1987. Factors influencing the standing crop of phytoplankton on the Australian Northwest Shelf seaward of the $40 \mathrm{~m}$ isobath. Continental Shelf Research 7, 115-133.

Uno, I., Eguchi, K., Yumimotot, K., Takemura, T., Shimizu, A., Uematsu, M., Liu, Z., Wang, Z., Hara, Y., Sugimoto, N., 2009. Asian dust transported one full circuit around the globe. Nature Geoscience 2, 557-560.

Viscarra Rossel, R., 2011. Fine-resolution multiscale mapping of clay minerals in Australian soils measured with near infrared spectra. J. Geophys. Res. 116.

Visser, F., Gerringa, L.J.A., Van der gaast, S.J., De baar, H.J.W., Timmermans, K.R., 2003. The Role Of The Reactivity And Content Of Iron Of Aerosol Dust On Growth Rates Of Two Antarctic Diatom Species. J. Phycol. 39, 1085-1094.

Waeles, M., Baker, A.R., Jickells, T., Hoogewerff, J., 2007. Global dust teleconnections: aerosol iron solubility and stable isotope composition. Environmental Chemistry 4, 233-237.

Wolff, E.W., Fischer, H., Fundel, F., Ruth, U., Twarloh, B., Littot, G.C., Mulvaney, R., Rothlisberger, R., de Angelis, M., Boutron, C.F., Hansson, M., Jonsell, U., Hutterli, M.A., Lambert, F., Kaufmann, P., Stauffer, B., Stocker, T.F., Steffensen, J.P., Bigler, M., Siggaard-Andersen, M.L., Udisti, R., Becagli, S., Castellano, E., Severi, M., Wagenbach, D., Barbante, C., Gabrielli, P., Gaspari, V., 2006. Southern Ocean sea-ice extent, productivity and iron flux over the past eight glacial cycles. Nature 440, 491-496.

Zhuang, G., Zhen, Y., Duce, R.A., Brown, P.R., 1992. Link between iron and sulfur cycles suggested by detection of Fe(II) in remote marine aerosols. Nature 355, 537-539. 


\section{Figure Captions}

Figure 1. Dust storm index (DSI) climatology for the LEB.

Figure 2 (a-l). Monthly maps of relative likelihoods of observing unequivocal links between dust and phytoplankton. Australian land colours are the relative likelihood of iron-rich dust entrainment (regions of very high vegetation cover (NDVI) and nonAustralian land are coloured green). Contours show relative likelihoods of wet and dry dust deposition from storms emanating from the Lake Eyre basin and are drawn at relative dust deposition frequencies of $0.01,0.03,0.1$, and 0.3 . Ocean colour gives the “receptivity index” based on average mixed layer irradiance and ecosystem state. Maps

are of the region $0^{0} \mathrm{~S}-60^{\circ} \mathrm{S}, 90^{0} \mathrm{E}-180^{0} \mathrm{E}$. Colourbar indicates relative likelihoods for land and ocean.

Figure 3. Biogeographical provinces in our study region (Longhurst, 2007). Map covers the region $0^{\circ}-60^{\circ} \mathrm{S}, 90^{\circ} \mathrm{E}-180^{\circ} \mathrm{E}$. 
Tables

Table 1. Data sets

\begin{tabular}{|c|c|c|c|c|}
\hline Data Type & $\begin{array}{l}\text { Spatial } \\
\text { Resolution }\end{array}$ & $\begin{array}{l}\text { Temporal } \\
\text { Resolution }\end{array}$ & $\begin{array}{l}\text { Climatology } \\
\text { Length }\end{array}$ & Source \\
\hline Soil Mineralogy & $30 \mathrm{~m}$ & Invariant & $\mathrm{n} / \mathrm{a}$ & $\begin{array}{l}\text { Viscarra- } \\
\text { Rossel (2011) }\end{array}$ \\
\hline Atmospheric transport & $10 \mathrm{~m}^{2}$ & $\begin{array}{l}\text { Daily } \\
\text { climatology }\end{array}$ & $20 \mathrm{yr}$ & $\begin{array}{l}\text { (McGowan } \\
\text { and Clark, } \\
\text { 2008) }\end{array}$ \\
\hline Dust Storm Index & $\mathrm{n} / \mathrm{a}$ & $\begin{array}{l}\text { Monthly } \\
\text { climatology }\end{array}$ & $50 \mathrm{yr}$ & $\begin{array}{l}\text { (McTainsh } \\
\text { and Tews, } \\
\text { 2007) }\end{array}$ \\
\hline Vegetation cover & $9 \mathrm{~km}$ & $\begin{array}{l}\text { Monthly } \\
\text { climatology }\end{array}$ & $12 \mathrm{yr}$ & $\begin{array}{l}\text { SeaWiFS } \\
\text { NDVI }\end{array}$ \\
\hline Precipitation & $0.25^{\circ}$ & $\begin{array}{l}\text { Monthly } \\
\text { climatology }\end{array}$ & $10 \mathrm{yr}$ & QuikSCAT \\
\hline Surface irradiance & $9 \mathrm{~km}$ & $\begin{array}{l}\text { Monthly } \\
\text { climatology }\end{array}$ & $12 \mathrm{yr}$ & SeaWiFS \\
\hline Ocean mixed layer depth & $1.0^{\circ}$ & $\begin{array}{l}\text { Monthly } \\
\text { climatology }\end{array}$ & $\mathrm{n} / \mathrm{a}$ & $\begin{array}{l}\text { Condie and } \\
\text { Dunn (2006) }\end{array}$ \\
\hline Nutrient & $\mathrm{n} / \mathrm{a}$ & Invariant & $\mathrm{n} / \mathrm{a}$ & (Longhurst, \\
\hline
\end{tabular}




\begin{tabular}{|l|l|l|l|l|}
\hline distribution/biogeographic & & & 2007) \\
provinces & $9 \mathrm{~km}$ & Monthly & $12 \mathrm{yr}$ & SeaWiFS/MO \\
\hline Chlorophyll $a$ & climatology & & DIS \\
\hline
\end{tabular}




\section{FIGURES}

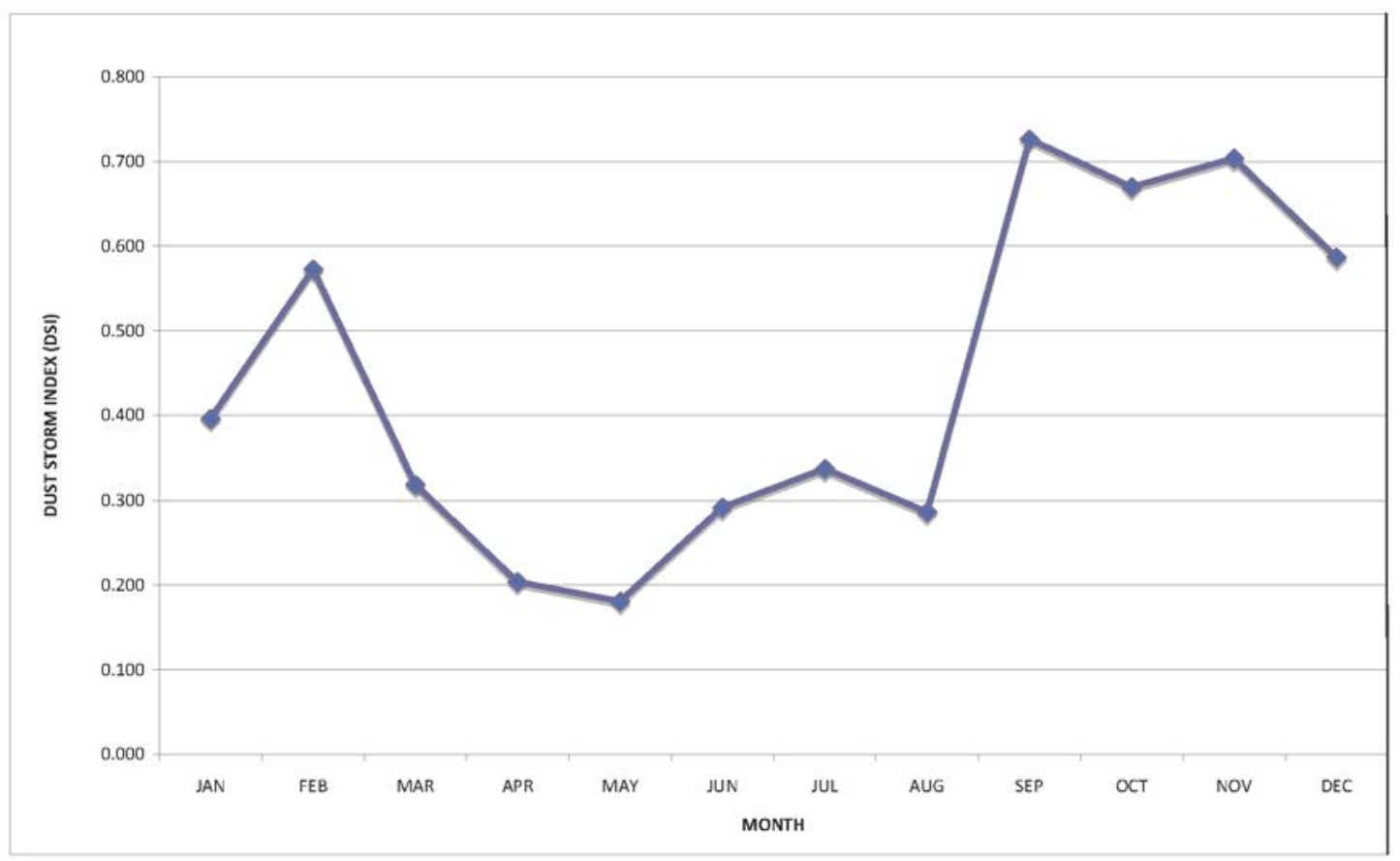

Figure 1. Dust storm index (DSI) climatology for the LEB. 
(a)

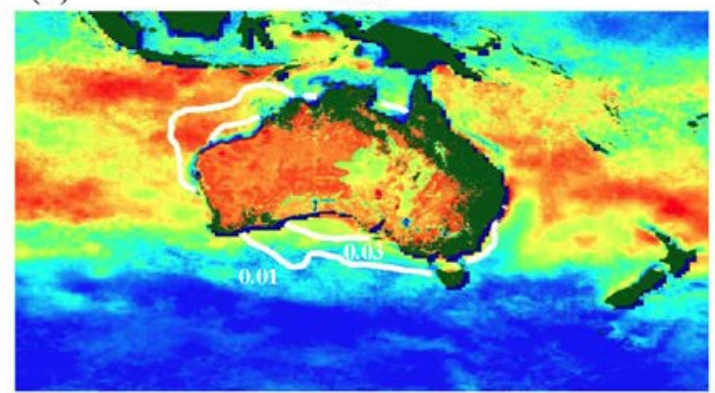

(c)

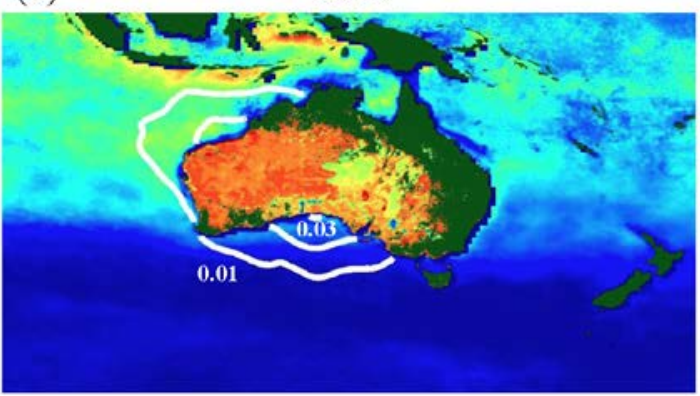

(e)

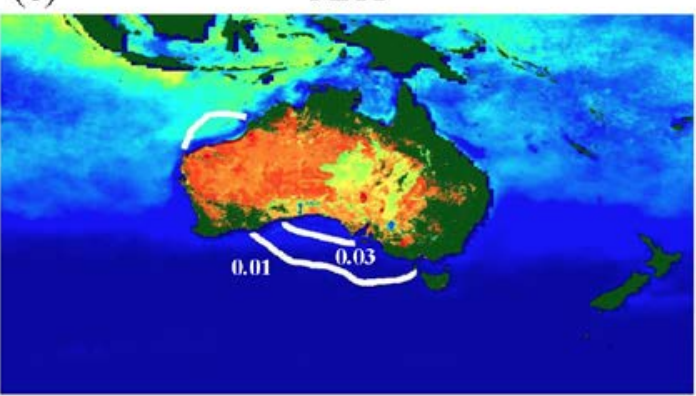

(b)

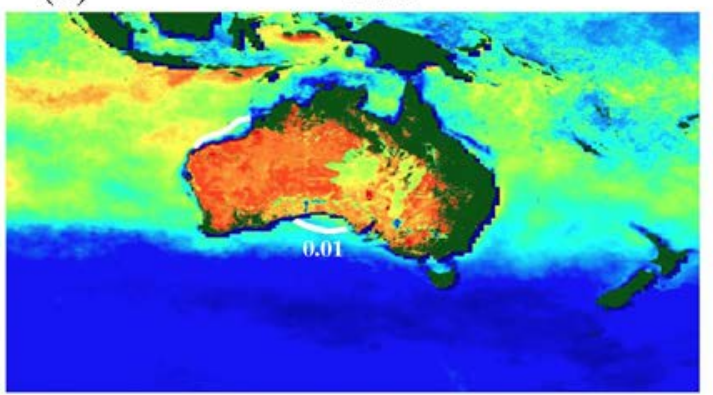

(d)

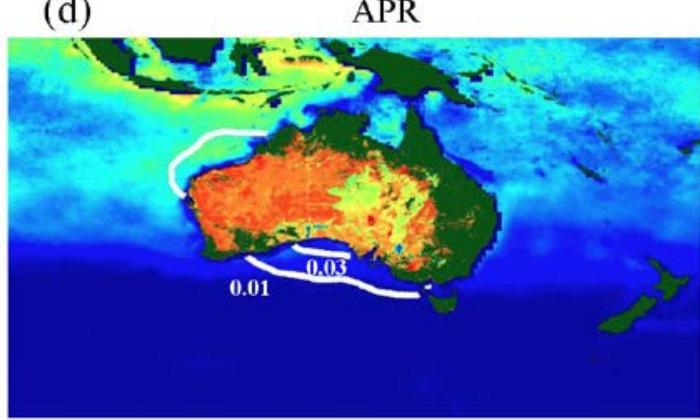

(f)

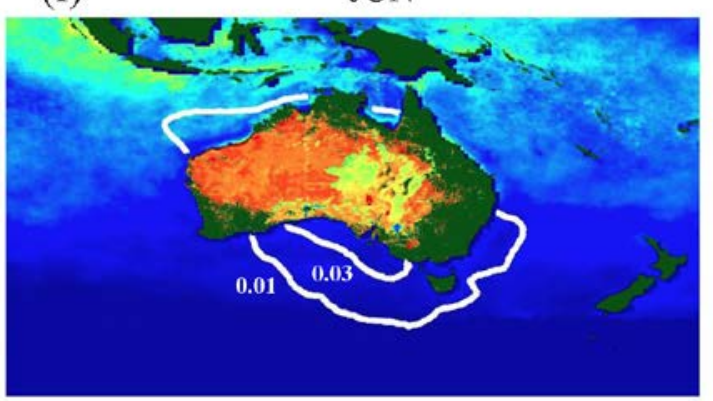

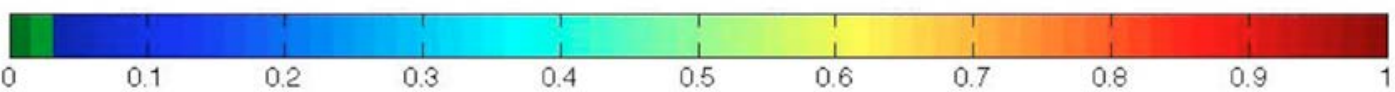


(g)

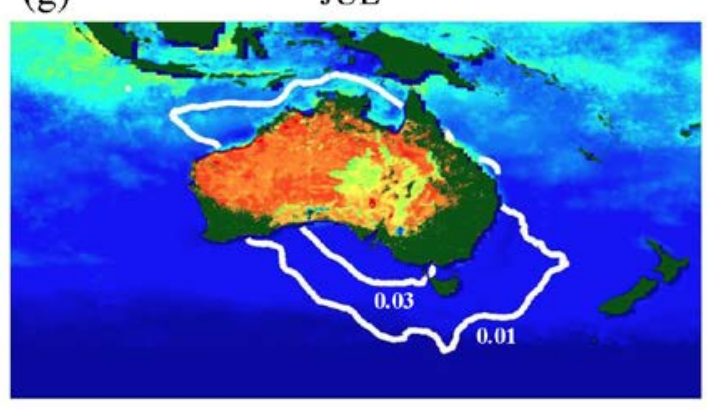

(i)

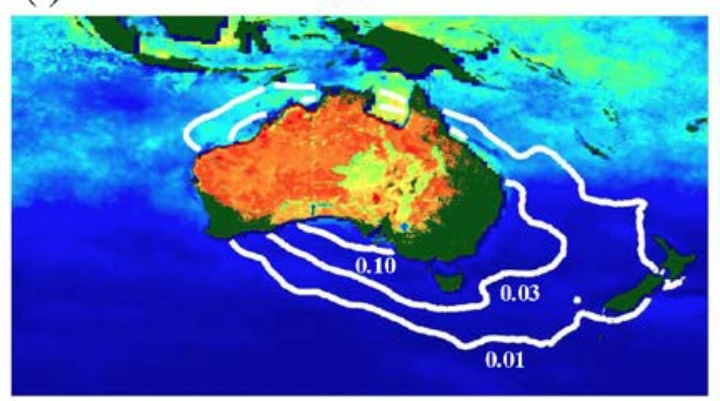

(k)

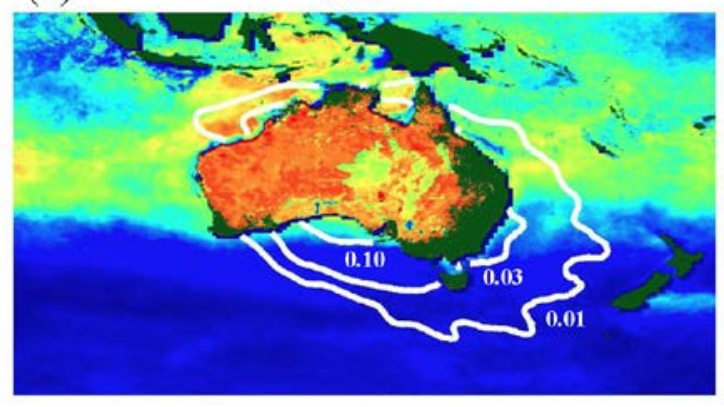

(h)

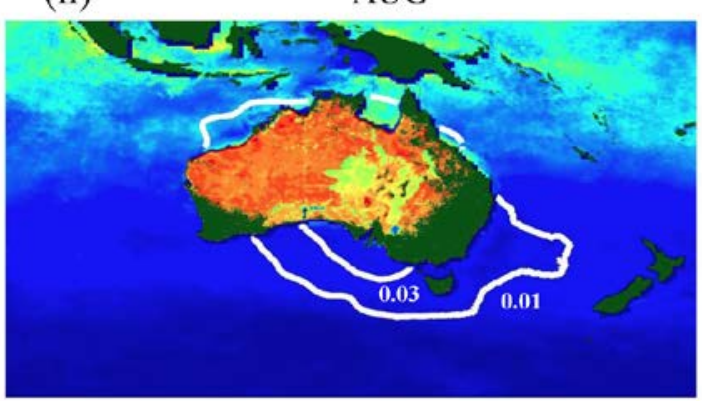

(j)

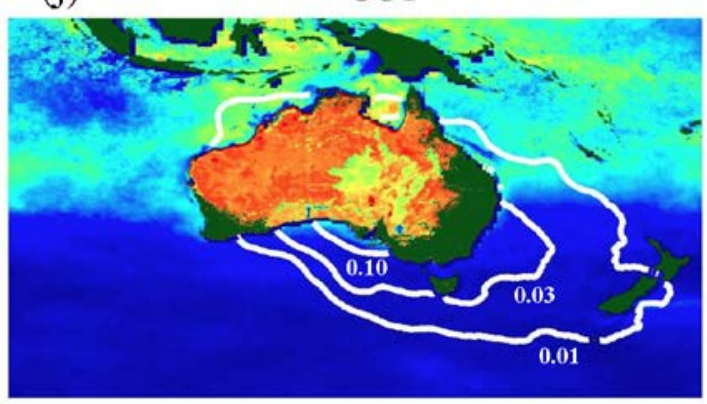

(1)

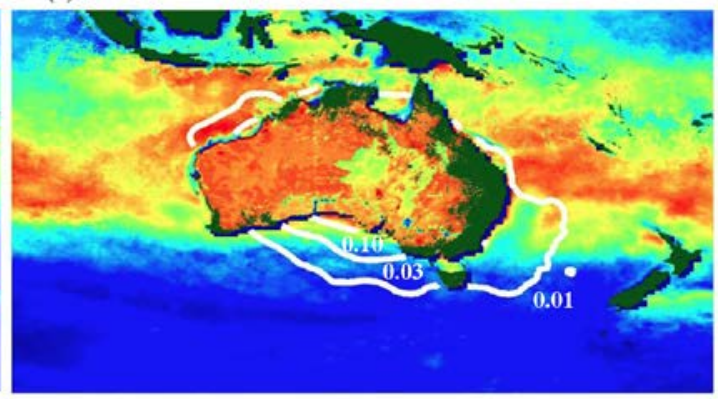

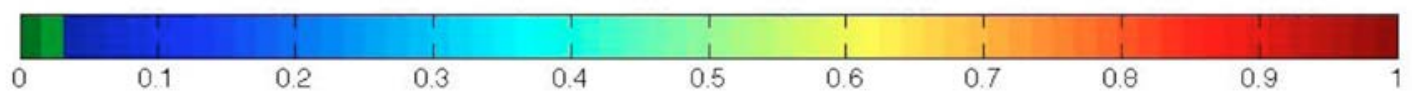

Figure 2 (a-l). Monthly maps of relative likelihoods of observing unequivocal links between dust and phytoplankton. Australian land colours are the relative likelihood of iron-rich dust entrainment (regions of very high vegetation cover (NDVI) and nonAustralian land are coloured green). Contours show relative likelihoods of wet and dry dust deposition from storms emanating from the Lake Eyre basin and are drawn at relative dust deposition frequencies of $0.01,0.03,0.1$, and 0.3 . Ocean colour gives the 
“receptivity index” based on average mixed layer irradiance and ecosystem state. Maps are of the region $0^{0} \mathrm{~S}-60^{\circ} \mathrm{S}, 90^{0} \mathrm{E}-180^{\circ} \mathrm{E}$. Colourbar indicates relative likelihoods for land and ocean.

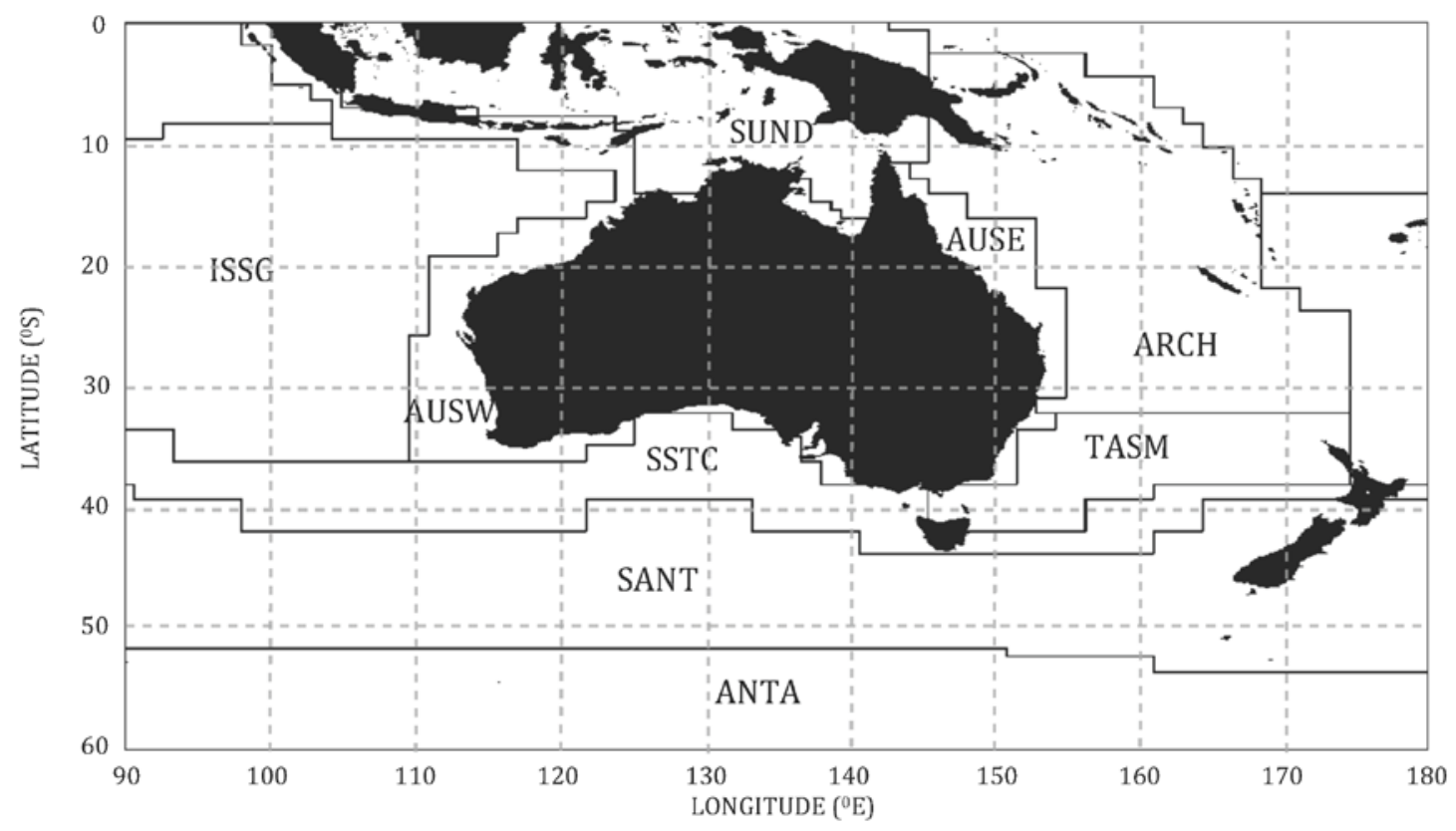

Figure 3. Biogeographical provinces in our study region (Longhurst, 2007). Map covers the region $0^{\circ}-60^{\circ} \mathrm{S}, 90^{\circ} \mathrm{E}-180^{\circ} \mathrm{E}$. 